\title{
Evaluation of the Physico-chemical, Thermal and Behavioral Properties of Ashwagandha Root Extract: Effects of Consciousness Energy Healing Treatment
}

\author{
Mahendra Kumar Trivedi ${ }^{1}$, Alice Branton ${ }^{1}$, Dahryn Trivedi ${ }^{1}$, Gopal Nayak ${ }^{1}$, \\ Ariadne Esmene Afaganis ${ }^{1}$, Barbara Marie Bader ${ }^{1}$, Brian A. Weekes ${ }^{1}$, Daphne Luisa Dumas ${ }^{1}$, \\ Denise Marie Fiedler ${ }^{1}$, Dennille Mellesia Smith ${ }^{1}$, Desi Pano ${ }^{1}$, Donna Felice Galla ${ }^{1}$, \\ Donna Maria Alija ${ }^{1}$, Elaine Barbara Mullins' ${ }^{1}$, Elaine M. Scorza', Ellia O'Donnell, \\ Fabio Massimo Paciucci ${ }^{1}$, Frances Goodman Warlick ${ }^{1}$, Haddon Norman Salt ${ }^{1}$, Inthirani Arul ${ }^{1}$, \\ Jacqueline Y. Andrews ${ }^{1}$, James Jay McLeran ${ }^{1}$, James Stephen Burnett ${ }^{1}$, Jean Caroline White ${ }^{1}$, \\ Parthasarathi Panda ${ }^{2}$, Kalyan Kumar Sethi ${ }^{2}$, Snehasis Jana ${ }^{2, *}$
}

${ }^{1}$ Trivedi Global, Inc., Henderson, Nevada, USA

${ }^{2}$ Trivedi Science Research Laboratory Pvt. Ltd., Bhopal, Madhya Pradesh, India

Email address:

publication@trivedieffect.com (S. Jana)

${ }^{*}$ Corresponding author

To cite this article:

Mahendra Kumar Trivedi, Alice Branton, Dahryn Trivedi, Gopal Nayak, Ariadne Esmene Afaganis, Barbara Marie Bader, Brian A. Weekes, Daphne Luisa Dumas, Denise Marie Fiedler, Dennille Mellesia Smith, Desi Pano, Donna Felice Galla, Donna Maria Alija, Elaine Barbara Mullins, Elaine M. Scorza, Ellia O'Donnell, Fabio Massimo Paciucci, Frances Goodman Warlick, Haddon Norman Salt, Inthirani Arul, Jacqueline Y. Andrews, James Jay McLeran, James Stephen Burnett, Jean Caroline White, Parthasarathi Panda, Kalyan Kumar Sethi, Snehasis Jana. Evaluation of the Physico-chemical, Thermal and Behavioral Properties of Ashwagandha Root Extract: Effects of Consciousness Energy Healing Treatment. International Journal of Pharmacy and Chemistry. Vol. 3, No. 3, 2017, pp. 41-51. doi: 10.11648/j.ijpc.20170303.13

Received: March 14, 2017; Accepted: April 4, 2017; Published: May 10, 2017

\begin{abstract}
Withania somnifera (Ashwagandha) root extract has a broad range of pharmacological activities due to the presence of many biologically active metabolites. The current study was designed to evaluate the influence of The Trivedi Effect $^{\circledR}$ - Consciousness Energy Healing Treatment (Biofield Energy Healing) on the physical, spectroscopic, thermal and behavioral properties of ashwagandha root extract using PXRD, PSD, FT-IR, UV-vis spectroscopy, TGA, and DSC analysis. Ashwagandha root extract was divided into two parts - one part was control without any Biofield Energy Treatment and another part was treated with the Consciousness Energy Healing Treatment remotely by twenty renowned Biofield Energy Healers and defined as Biofield Energy Treated sample. The PXRD analysis exhibited that both the control and treated samples were amorphous in nature. The particle size values at $\mathrm{d}_{10}, \mathrm{~d}_{50}$, and $\mathrm{d}_{90}$ of the treated sample were increased significantly by $8.69 \%, 7.32 \%$, and $6.50 \%$, respectively compared with the control sample. Similarly, the surface area of the treated sample was significantly decreased by $12.69 \%$ compared to the control sample. The FT-IR analysis indicated no significant alteration of the force constant for the functional groups in the treated sample compared to the control sample. The UV-vis analysis revealed that the wavelength for the maximum absorbance of the control and treated samples were at 207.5 and $205.2 \mathrm{~nm}$, respectively. The TGA revealed the two major thermal degradation steps and the total weight loss was decreased by $0.86 \%$ in the treated sample compared with the control sample. Consequently, the maximum thermal degradation temperature at $273.53^{\circ} \mathrm{C}$ and $389.39^{\circ} \mathrm{C}$ for two broad peaks in treated sample was increased by $0.78 \%$ and $0.31 \%$, respectively compared to the control the sample $\left(271.40^{\circ} \mathrm{C}\right.$ and $\left.388.48^{\circ} \mathrm{C}\right)$. The DSC analysis indicated that the evaporation temperature was significantly increased by $10.95 \%$ in the Biofield Energy Treated sample with a $5.34 \%$ reduced the latent heat of vaporization compared with the control sample. The overall thermal analysis indicated that the treated sample was thermally more stable as compared to the control sample. The Trivedi Effect ${ }^{\circledR}$ - Energy of Consciousness Healing Treatment might lead to have better powder flowability and long-term storage stability compared with the control sample. Thus, the treated ashwagandha root extract might provide better therapeutic response against inflammatory diseases, immunological disorders, stress, arthritis,
\end{abstract}


cancer, diabetes, sexual disorders, ageing, and other chronic infections.

Keywords: Withania somnifera, The Trivedi Effect ${ }^{\circledR}$, Biofield Energy Healing Treatment, Consciousness Energy Healing, PXRD, Particle Size, TGA, DSC

\section{Introduction}

The use of the herbal medicines are increasing day-by-day throughout the world due to its impressive therapeutic effects and fewer side effects as compared to the allopathic medicines [1]. Withania somnifera is a vital herb, traditionally known as 'Ashwagandha' or winter cherry. In Ayurveda, it is defined as 'Indian ginseng'. Ashwagandha is widely used in the most of the Indian herbal medicine and nutraceuticals for the treatment of various diseases including nervous and sexual disorders, infectious diseases, diabetes, cancer, ulcer, stress, immunological disorders, arthritis, etc. From the ancient time, it is used as a tonic to arrest the ageing process, rejuvenate the body and boost the defense against infectious disorders and also promote the longevity [2-11]. As ashwagandha root extract contains a wide array of nutrients and phytochemicals, it is used as a dietary supplement for the better quality of life [3]. The major active phytoconstituents of ashwagandha root extract are highly oxygenated withanolides. Withanolides have C28 steroidal nucleus with C9 side chain, having a six membered lactone ring (Figure 1). The oxidation at various sites of the skeleton is responsible for the structural deviations in different classes of withanolides [11-14].

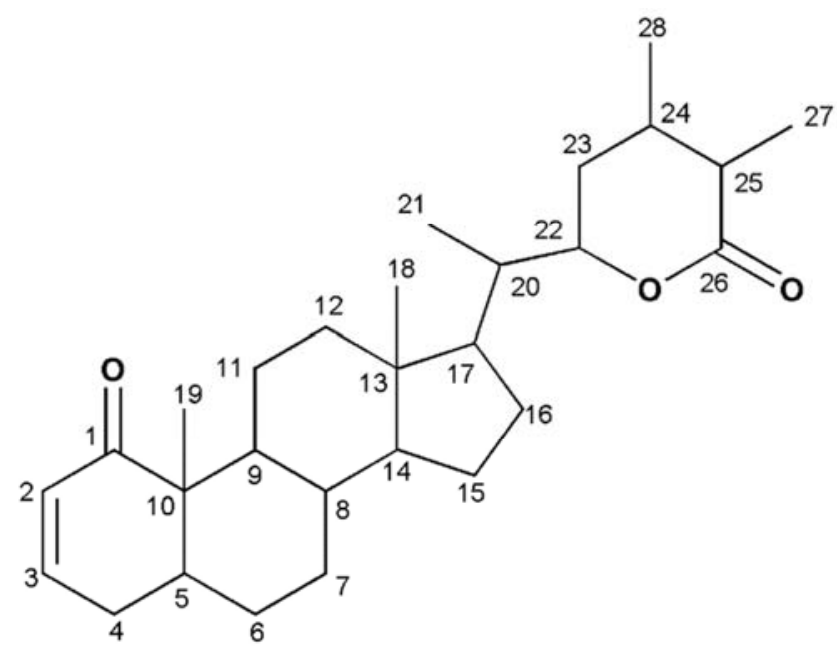

Figure 1. The basic skeleton of withanolide.

Literatures reported that withanolides such as withaferin A, withanolide $\mathrm{D}$, withanolide $\mathrm{E}$, etc. possess various pharmacological activities including antioxidant, anticancer, immunomodulating, neuroprotective, antiepileptic, antibacterial, adaptogenic, spermatogenic, antianxiety, antidepression, hepatoprotective, anti-inflammatory, antiarthritic, antimicrobial, hypoglycaemic, hypolipidemic, aphrodisiac, antiulcer, radiosensitizing, etc. [11, 14-19].
Therefore, a new proprietary herbomineral formulation was formulated that consisted of herbal product like ashwagandha root extract along with minerals such as zinc, magnesium, and selenium. This herbomineral formulation is designed as nutraceutical supplement and can be used for the prevention and treatment of various human disorders.

From the ancient-time, the living force preserved by every living organisms that contributes the 'life' is defined as prana by the Hindus, $q i$ or $c h i$ by the Chinese, and $k i$ by the Japanese. This is believed to co-relate with the soul, spirit, and mind. This hypothetical vital force is considered now as the Bioenergetics Field. The Biofield Energy Field is a dynamic electromagnetic field existing surround of the human body. The Biofield Energy is infinite and paradimensional. It can freely flow between the human and environment that leads to the continuous movement or matter of energy $[20,21]$. Thus, the human has the ability to harness energy from the earth, the "universal energy field" and transmit it to any living or nonliving object(s) around the globe. The objects always receive the energy and respond in a useful way. This process is known as Biofield Energy Healing Treatment [22, 23]. Biofield (Putative Energy Fields) based Energy Therapies are used worldwide to promote health and healing [24]. The National Center of Complementary and Integrative Health (NCCIH) has been recognized and accepted Biofield Energy Healing as a Complementary and Alternative Medicine (CAM) health care approach in addition to other therapies, medicines and practices such as natural products, deep breathing, yoga, Tai Chi, Qi Gong, chiropractic/osteopathic manipulation, meditation, massage, special diets, homeopathy, progressive relaxation, guided imagery, acupressure, acupuncture, relaxation techniques, hypnotherapy, healing touch, movement therapy, pilates, rolfing structural integration, mindfulness, Ayurvedic medicine, traditional Chinese herbs and medicines, naturopathy, essential oils, aromatherapy, Reiki, cranial sacral therapy, and applied prayer (as is common in all religions, like Christianity, Hinduism, Buddhism and Judaism) [25]. The Biofield Energy Treatment (The Trivedi Effect ${ }^{\circledR}$ ) has been extensively studied with significant outcomes in many scientific fields such as cancer research [26]; altered antimicrobial sensitivity of pathogenic microbes in microbiology [27-29], biotechnology [30, 31], genetics $[32,33]$; altered structure of the atom in relation to the various metals, ceramics, polymers and chemicals materials science [34-36]; altered physical and chemical properties of pharmaceuticals $[37,38]$, nutraceuticals [39, 40], organic compounds [41-43]; and improved overall growth and yield of plants in agricultural science [44, 45]. Herbal extracts and it's formulations despite of their outstanding in vitro results exhibited poor or low in vivo 
activity, because of their low lipid solubility or improper molecular size, causing in deprived absorption and thus poor bioavailability [1]. According to the recent study on the bioavailability of major withanolides of Withania somnifera, Devkar et al. demonstrated that the nonpolar and low molecular weight withanolides are highly permeable, whereas the high glycosylated and polar withanolides displayed low permeability in their in vitro absorption model system [46]. For instance, ashwagandha root extract has the outstanding nutrition and medicinal values, researchers are still working on to find out an optimal dosage range for reproducing the desired effects in human as well as to determine the safe, non-toxic and effective dosage form [47]. The physicochemical properties such as particle size, crystalline structure, crystallite size, surface area, etc. and thermal properties of a drug play a vital role in bioavailability as well as stability of the drug during processing, formulation, storage, and packaging [48, 49]. Biofield Energy Treatment (The Trivedi Effect ${ }^{\mathbb{B}}$ ) has been reported to change the particle size, specific surface area, crystalline, chemical and thermal behavior of an atom/ion through possible mediation of the neutrinos [50]. By considering all these aspect, the objective of the current study was to examine whether the Biofield Energy Treatment can change the physical, structural, and thermal properties of ashwagandha root extract in such a way that might be assist in the improvement of the solubility and absorption of ashwagandha root extract and also help in designing of any suitable pharmaceutical formulation. The physical, spectroscopic, and thermal properties of both control and the Biofield Energy Treated ashwagandha root extracts were evaluated using various analytical techniques include Fourier transform infrared (FT-IR) spectrometry, ultraviolet-visible (UV-vis) spectroscopy, Powder X-ray diffraction (PXRD), particle size distribution analysis (PSD), thermogravimetric analysis (TGA), and differential scanning calorimetry (DSC).

\section{Materials and Methods}

\subsection{Chemicals and Reagents}

Withania somnifera (Ashwagandha) root hydroalcoholic extract was purchased from Sanat Product Ltd., India. All other chemicals used in the experiment were of analytical grade available in India.

\subsection{Consciousness Energy Healing Treatment Strategies}

Ashwagandha root extract powder was one of the components of the new proprietary herbomineral formulation, developed by our research team, and it was used per se as the test compound for the current study. The test compound was divided into two parts, one part of the test compound was treated with The Trivedi Effect ${ }^{\circledR}$ Consciousness Energy Healing Treatment (Biofield Energy Healing) by renowned Biofield Energy Healers and defined as Biofield Energy Treated sample, while the second part of the test compound did not receive any sort of such treatment and defined as untreated or control ashwagandha root extract sample. The Trivedi Effect ${ }^{\circledR}$ treatment was provided by the group of twenty renowned Biofield Energy Healers who participated in this study and performed the Biofield Energy Treatment (The Trivedi Effect ${ }^{\mathbb{B}}$ ) remotely. Eighteen Biofield Energy Healers were remotely located in the U.S.A. and two of which were remotely located in Canada, while the test compound was located in the research laboratory of GVK Biosciences Pvt. Ltd., Hyderabad, India. The Trivedi Effect ${ }^{\circledR}$ - Consciousness Energy Healing Treatment was provided for 5 minutes through Healer's Unique Energy Transmission process remotely to the test compound under the laboratory conditions. None of the Biofield Energy Healers in this study visited the laboratory in person, nor had any contact with the compounds. Similarly, the control sample was subjected to "sham" healers for 5 minutes, under the same laboratory conditions. The sham healer did not have any knowledge about Biofield Energy Treatment. After that, the treated and untreated samples were kept in similar sealed conditions and characterized thoroughly by PXRD, PSD, FT-IR, UV-visible spectroscopy, TGA, and DSC analysis.

\subsection{Characterization}

\subsubsection{Powder X-Ray Diffraction (PXRD) Analysis}

The PXRD analysis was accomplished on PANalytical X'Pert Pro powder X-ray diffractometer system. The X-ray of wavelength $1.54056 \AA$ was used. The data was collected in

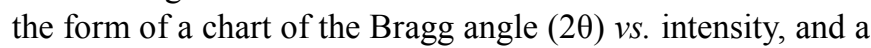
detailed table containing information on peak intensity counts, d value $(\AA)$, relative intensity (\%), full width half maximum (FWHM) $\left(\theta^{\circ}\right)$. From the XRD results, the crystallite size $(\mathrm{G})$ was calculated using $X$ 'pert data collector and X'pert high score plus processing software. A total of $\sim 500 \mathrm{mg}$ of the control and treated samples individually were used for the analysis and prepared by back loading technique using the sample preparation kit. The sample was spread on the holder ring in sufficient quantity to fill the ring cavity. It was then pressed down using powder press block and scrap the powder that was in surplus using a glass slide to get densely packed specimen. Consequently, the bottom plate was placed onto the holder ring and clamp in position. The sample holder was then removed from the sample preparation table by turning it upside down. A smooth surface of sample was obtained to ensure optimum results.

\subsubsection{Particle Size Distribution (PSD) Analysis}

The average particle size and particle size distribution were analyzed using Malvern Mastersizer 2000, UK with a detection range between $0.01 \mu \mathrm{m}$ to $3000 \mu \mathrm{m}$. The sample unit was filled with the dispersant medium and operated the stirrer at $2500 \mathrm{rpm}$. Alignment of the optics was done and the background measurement was taken. After the background measurement, the sample was added in to the sample unit with constant monitoring the obscuration and stopped the addition of sample when the obscuration reached in between $15 \%$ to $20 \%$. When the obscuration was stable, the measurement was taken twice and the average was taken of 
two measurements. The average histogram of the two measurements was recorded. Along with histogram, the data was presented in table format which include particle size $(\mu \mathrm{m})$. Also, the values at below 10\% level $\left(\mathrm{d}_{10}\right), 50 \%$ level $\left(d_{50}\right)$, and $90 \%$ level $\left(d_{90}\right)$ were calculated from the histogram and the calculations such as surface area $\left(\mathrm{m}^{2} / \mathrm{g}\right)$ were done by using software Mastersizer 2000.

Percent change in particle size (d) for at below $10 \%$ level $\left(\mathrm{d}_{10}\right), 50 \%$ level $\left(\mathrm{d}_{50}\right)$, and $90 \%$ level $\left(\mathrm{d}_{90}\right)$ was calculated using following equation 1 :

$$
\% \text { change in particle size }=\frac{\left[\mathrm{d}_{\text {Treated }}-\mathrm{d}_{\text {Control }}\right]}{\mathrm{d}_{\text {Control }}} \times 100
$$

Where, $\mathrm{d}_{\text {Control }}$ and $\mathrm{d}_{\text {Treated }}$ are the particle size $(\mu \mathrm{m})$ for at below $10 \%$ level $\left(\mathrm{d}_{10}\right), 50 \%$ level $\left(\mathrm{d}_{50}\right)$, and $90 \%$ level $\left(\mathrm{d}_{90}\right)$ of the control and treated samples, respectively.

Percent change in surface area $(\mathrm{S})$ was calculated using following equation 2 :

$$
\% \text { change in surface area }=\frac{\left[\mathrm{S}_{\text {Treated }}-\mathrm{S}_{\text {Control }}\right]}{\mathrm{S}_{\text {Control }}} \times 100
$$

Where, $\mathrm{S}_{\text {Control }}$ and $\mathrm{S}_{\text {Treated }}$ are the surface area of the control and treated samples, respectively.

\subsubsection{Fourier Transform Infrared (FT-IR) Spectroscopy}

FT-IR spectroscopy of ashwagandha root extract was performed on Spectrum two (Perkin Elmer, USA) Fourier transform infrared spectrometer with the frequency array of $400-4000 \mathrm{~cm}^{-1}$ by using pressed $\mathrm{KBr}$ disk technique.

\subsubsection{Ultra Violet-Visible Spectroscopy (UV-Vis) Analysis}

The UV-Vis spectral analysis was carried out using Shimadzu UV-2450 with UV Probe, Japan. The spectrum was recorded using $1 \mathrm{~cm}$ quartz cell that has a slit width of $1.0 \mathrm{~nm}$. The wavelength range chosen for recording the spectra was 190-800 nm. The absorbance spectra (in the range of 0.2 to 0.9 ) and wavelength of maximum absorbance $\left(\lambda_{\max }\right)$ were recorded.

\subsubsection{Thermal Gravimetric Analysis (TGA)}

TGA analysis was performed using Instrument TGA Q50 (TA Instruments, USA) at a heating rate of $10^{\circ} \mathrm{C} / \mathrm{min}$ from room temperature i.e. $30^{\circ} \mathrm{C}$ to $900^{\circ} \mathrm{C}$ under nitrogen atmosphere. A total of $\sim 14 \mathrm{mg}$ of sample was used for the analysis and was taken on the platinum pan. In TGA, the weight loss for each step was recorded in grams as well as in percent loss with respect to the initial weight. Also, the onset, endset, and peak temperature for each step were recorded in TGA.

Percent change in weight loss (W) was calculated using following equation 3 :

$$
\% \text { change in weight loss }=\frac{\left[\mathrm{w}_{\text {Treated }}-\mathrm{W}_{\text {Control }}\right]}{\mathrm{W}_{\text {Control }}} \times 100
$$

Where, $\mathrm{W}_{\text {Control }}$ and $\mathrm{W}_{\text {Treated }}$ are the weight loss of the control and The Trivedi Effect ${ }^{\circledR}$ treated samples, respectively.

\subsubsection{Differential Scanning Calorimetry (DSC)}

Analysis was performed using the DSC Q20 (TA Instruments, USA) differential scanning calorimeter. A total of $\sim 4 \mathrm{mg}$ sample was weighed and sealed in aluminum pan and equilibrated at $25^{\circ} \mathrm{C}$ and heated up to $450^{\circ} \mathrm{C}$ at the heating rate of $10^{\circ} \mathrm{C} / \mathrm{min}$ under nitrogen gas as purge atmosphere with flow rate of $50 \mathrm{~mL} / \mathrm{min}$. The value for onset, endset, peak temperature, peak height ( $\mathrm{mJ}$ or $\mathrm{mW})$, peak area, and change in heat $(\mathrm{J} / \mathrm{g})$ for each peak were recorded.

Percent change in melting point $(\mathrm{T})$ was calculated using following equation 4 :

$$
\% \text { change in melting point }=\frac{\left[\mathrm{T}_{\text {Treated }}-\mathrm{T}_{\text {Control }}\right]}{\mathrm{T}_{\text {Control }}} \times 100
$$

Where, $\mathrm{T}_{\text {Control }}$ and $\mathrm{T}_{\text {Treated }}$ are the melting point of the control and treated samples, respectively.

Percent change in latent heat of fusion $(\Delta \mathrm{H})$ was calculated using following equation 5 :

$\%$ change in latent heat of fusion $=\frac{\left[\Delta \mathrm{H}_{\text {Treated }}-\Delta \mathrm{H}_{\text {Control }}\right]}{\Delta \mathrm{H}_{\text {Control }}} \times 100(5)$

Where, $\Delta \mathrm{H}_{\text {Control }}$ and $\Delta \mathrm{H}_{\text {Treated }}$ are the latent heat of fusion of the control and treated samples, respectively.

\section{Results and Discussion}

\subsection{Powder X-Ray Diffraction (PXRD) Analysis}

Powder X-ray diffraction study was conducted to examine the crystalline pattern of the control and treated ashwagandha root extract. Figures 2 showed the PXRD diffractograms of both the control and Biofield Energy Treated did not contribute any diffraction peaks. It was then concluded that both samples are amorphous in nature and the Biofield Energy Treatment has no effect compared to the control sample.
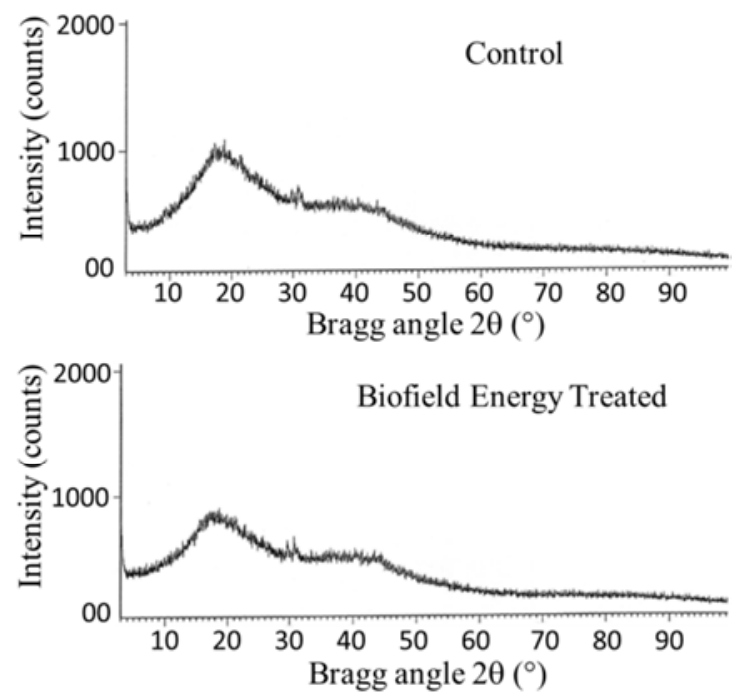

Figure 2. PXRD diffractograms of the control and Biofield Energy Treated W. somnifera (Ashwagandha) root extract. 


\subsection{Particle Size Distribution (PSD) Analysis}

Particle size data of both the control and Biofield Energy Treated ashwagandha root extract was investigated and the results are presented in Table 1. The particle size values of the Biofield Energy Treated ashwagandha root extract at $\mathrm{d}_{10}$, $\mathrm{d}_{50}$, and $\mathrm{d}_{90}$ were significantly increased by $8.69 \%, 7.32 \%$, and $6.50 \%$, respectively compared with the control sample (Table 1). Similarly, the surface area of the Biofield Energy Treated ashwagandha root extract $\left(0.075 \mathrm{~m}^{2} / \mathrm{g}\right)$ was significantly decreased by $12.69 \%$ compared with the control sample $\left(0.086 \mathrm{~m}^{2} / \mathrm{g}\right)$.

Table 1. Particle size $\left(d_{10}, d_{50}\right.$, and $\left.d_{90}\right)$ and surface area of the control and Biofield Energy Treated W. somnifera (Ashwagandha) root extract.

\begin{tabular}{lllll}
\hline Parameter & $\mathbf{d}_{\mathbf{1 0}}(\boldsymbol{\mu} \mathbf{m})$ & $\mathbf{d}_{\mathbf{5 0}}(\boldsymbol{\mu m})$ & $\mathbf{d}_{\mathbf{9 0}}(\boldsymbol{\mu m})$ & Surface $\operatorname{area}\left(\mathbf{m}^{2} / \mathbf{g}\right)$ \\
\hline Control & 70.35 & 181.61 & 356.10 & 0.086 \\
Biofield Energy Treated & 76.46 & 194.91 & 379.24 & 0.075 \\
Percent change (\%) & 8.69 & 7.32 & 6.50 & -12.69 \\
\hline
\end{tabular}

*denotes the percentage change in the particle size $\left(\mathrm{d}_{10}, \mathrm{~d}_{50}\right.$, and $\left.\mathrm{d}_{90}\right)$ and surface area of the Biofield Energy Treated sample with respect to the control sample.

The results revealed that there might be an effect of Biofield Energy Treatment on the intrinsic properties of ashwagandha root extract. Numerous literatures mentioned that particle size, shape and surface area of the pharmaceuticals/nutraceuticals have an important impact on solubility, dissolution rate, in vivo bioavailability, dose uniformity and therapeutic efficacy as well as assist in the design of the new drug delivery systems [48, 51]. Introduction of the external force leads to the transform the small particles into larger particles. The various reasons to increase the particle size are enhanced flowability, improved product shape and appearance [52]. It is assumed that Biofield Energy Healing Treatment (i.e. consider as external force) might improve the flowability, shape and appearance of ashwagandha root extract.

\subsection{Fourier Transform Infrared (FT-IR) Spectroscopy}

The FT-IR spectra of both the control and Consciousness Energy Healing Treated ashwagandha root extract are presented in Figure 3. The FT-IR spectral data are presented in Table 2. The wavenumber of the absorbance $(v)$ of a diatomic can be calculated from the following equation derived from the Hooke's law (Equation 6):

$$
v=\frac{1}{2 \pi c} \sqrt{\frac{f\left(m_{1}+m_{2}\right)}{m_{1} m_{2}}}
$$

Where, $v=$ vibrational frequency $\left(\mathrm{cm}^{-1}\right), \mathrm{c}=$ the velocity of light $(\mathrm{cm} / \mathrm{s}), \mathrm{m}_{1}$ and $\mathrm{m}_{2}=$ the mass of atoms 1 and 2 , respectively, in $\mathrm{g}, \mathrm{f}=$ the force constant of the bond (dyne/cm).

From the above equation (6), it has been shown that if other factors remain constant, the vibrational frequency (wavenumber) is directly proportional to the force constant i.e. for a certain functional group (for e.g. $-\mathrm{C}=\mathrm{O}$ ), changes in the vibrational frequency (wavenumber) indicate the alteration of the force constant. Several factors such as hybridization, resonance, bond strength, conjugation, etc. can affect the force constant $[53,54]$.

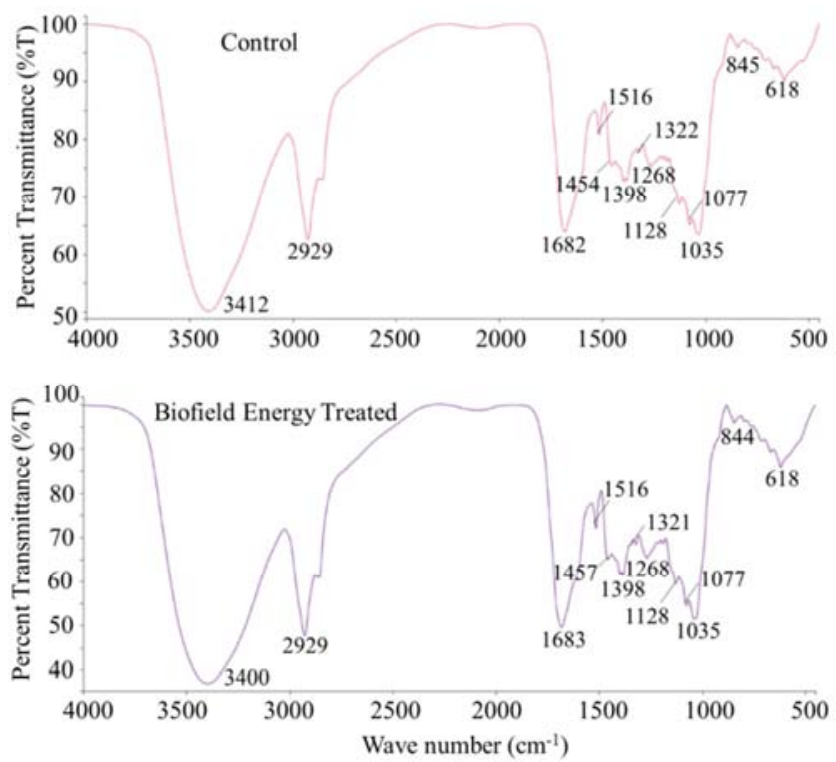

Figure 3. FT-IR spectra of the control and Biofield Energy Treated W. somnifera (Ashwagandha) root extract.

It has been observed that the vibrational frequencies for the $\mathrm{O}-\mathrm{H}, \mathrm{C}-\mathrm{H}, \mathrm{C}-\mathrm{C}, \mathrm{C}-\mathrm{O}$, and $\mathrm{C}=\mathrm{O}$ groups of the Biofield Energy Treated ashwagandha were almost similar to the control sample (Table 2, entry 1-7). It indicated that the force constant of these groups was remained unchanged. The presence of epoxide, unsaturated lactone, 1-keto-2-ene functions play a vital role to elicit the pharmacological activities of withanolides [14, 55-57]. In summary, the structural properties of the phytoconstituents present in the ashwagandha root powder extract remained unaltered due to the Biofield Energy Healing Treatment.

Table 2. FT-IR data of the control and Biofield Energy Treated W. somnifera (Ashwagandha) root extracts.

\begin{tabular}{llll}
\hline \multirow{2}{*}{ Entry No. } & Mode of vibration & \multicolumn{2}{c}{${\left.\text { Characteristic absorption (s) of ashwagandha root extract (cm }{ }^{-1}\right)}^{\text {Biofield Treated }}$} \\
\cline { 3 - 4 } & & Control & 3400 \\
\hline 1 & O-H stretching & 3412 & 2929 \\
\hline
\end{tabular}




\begin{tabular}{llll}
\hline \multirow{2}{*}{ Entry No. } & \multirow{2}{*}{ Mode of vibration } & \multicolumn{2}{l}{ Characteristic absorption $(\mathbf{s})$ of ashwagandha root extract $\left(\mathbf{c m}^{-1}\right)$} \\
\cline { 3 - 4 } & & Control & Biofield Treated \\
\hline 3 & C=O stretching $(\alpha, \beta$-unsaturated ketone) & 1682 & 1683 \\
4 & C-C stretching & $1516,1454,1398,1322$ & $1516,1457,1398,1321$ \\
5 & C-O in epoxide & 1268 & 1268 \\
6 & C-O in alkoxy & 1128,1077, & 1128 \\
& & 1035 & 1077,1035 \\
7 & C-H aromatic bending & 845,618 & 844,618 \\
\hline
\end{tabular}

\subsection{Ultraviolet-Visible Spectroscopy (UV-Vis) Analysis}
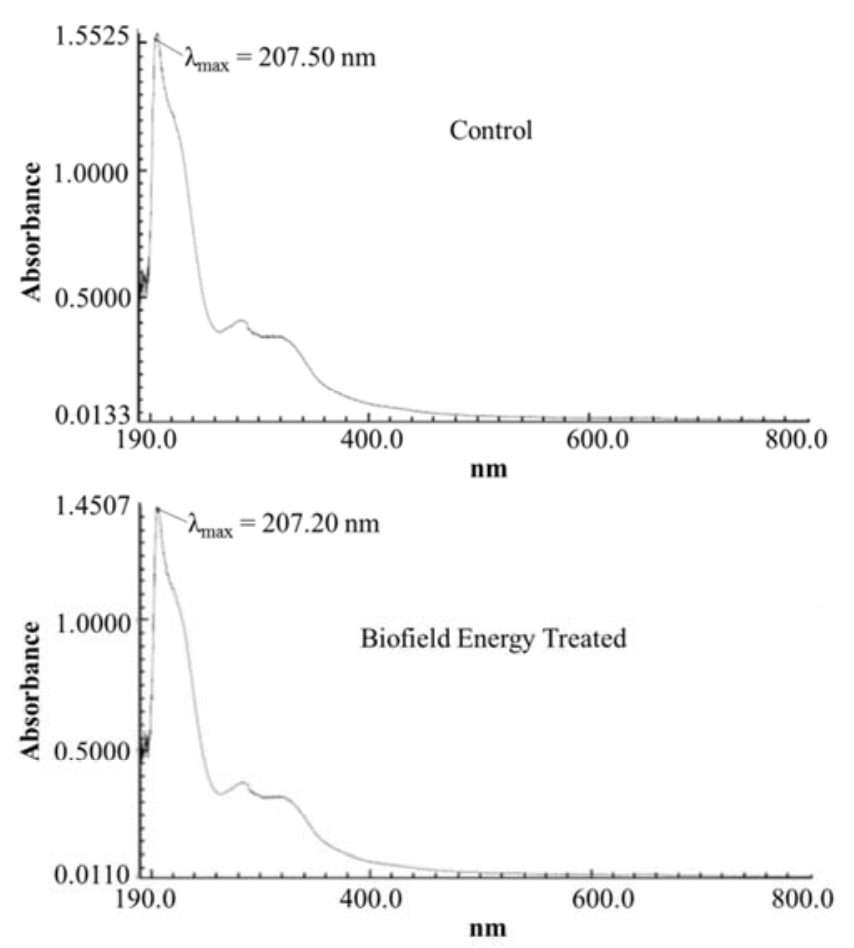

Figure 4. UV-vis spectra of the control and Biofield Energy Treated W. somnifera (Ashwagandha) root extracts.

The UV-visible spectra of both the control and Biofield Energy Treated ashwagandha root extracts are shown in the
Figure 4. The wavelength for the maximum absorbance $\left(\lambda_{\max }\right)$ of both the control and Biofield Energy Treated ashwagandha root extracts were at 207.50 and $207.20 \mathrm{~nm}$, respectively and there was a minor shift of absorbance maxima from 1.5548 in the control sample to 1.4372 in the Biofield Energy Treated sample. The UV absorbance occurs due to the different type of energy transitions from the singlet to the singlet excited state such as $\sigma \rightarrow \sigma^{*}, n \rightarrow \pi^{*}$, and $\pi \rightarrow \pi^{*}$. These type of electronic transitions are happened when the difference in energy between the lowest unoccupied molecular orbital (LUMO) and the highest occupied molecular orbital (HOMO) is significantly higher than the activation energy of the compound [59]. It has been reported that the wavelength for the maximum absorbance for the ashwagandha root extract was at $208.50 \mathrm{~nm}$. Thus, no significant change in the $\lambda_{\max }$ of the Biofield Energy Treated sample was observed as compared to the control sample. Hence, it is anticipated that the structure of the phytoconstituents in the treated sample was remained unaffected as compared to the control sample.

\subsection{Thermal Gravimetric Analysis (TGA)}

TGA was applied to investigate the thermal stability of the control and Biofield Energy Treated ashwagandha root extracts. The TGA analysis exhibited three steps of thermal degradation as mentioned in Table 3 and Figure 5.

Table 3. Thermal degradation steps of the control and Biofield Energy Treated W. somnifera (Ashwagandha) root extract.

\begin{tabular}{|c|c|c|c|c|c|}
\hline \multirow{2}{*}{ S. No. } & \multicolumn{2}{|c|}{ Temperature $\left({ }^{\circ} \mathrm{C}\right)$} & \multicolumn{2}{|c|}{ \% Weight loss } & \multirow{2}{*}{ \% Change } \\
\hline & Control & Treated & Control & Treated & \\
\hline $1^{\text {st }}$ step of degradation & 185.00 & 185.00 & 9.04 & 8.81 & -2.54 \\
\hline $2^{\text {nd }}$ step of degradation & 485.00 & 485.00 & 60.94 & 60.64 & -0.49 \\
\hline $3^{\text {rd }}$ step of degradation & 895.88 & 895.82 & 9.79 & 9.63 & -1.63 \\
\hline Total weight loss & - & - & 79.77 & 79.08 & -0.86 \\
\hline
\end{tabular}

*denotes the percentage change in the weight loss of the Biofield Energy Treated sample with respect to the control sample.

In the $1^{\text {st }}, 2^{\text {nd }}$, and $3^{\text {rd }}$ steps of thermal degradation, the weight loss of the Biofield Energy Treated ashwagandha root extract was decreased by $2.54 \%, 0.49 \%$ and $1.63 \%$, respectively compared with the control sample as shown in the Table 3. However, the total weight loss of the
Biofield Energy Treated sample (79.77\%) was reduced by $0.86 \%$ compared with the control sample $(79.08 \%)$. It is then anticipated that Biofield Energy Healing Treatment might enhance the thermal stability of ashwagandha root extract. 

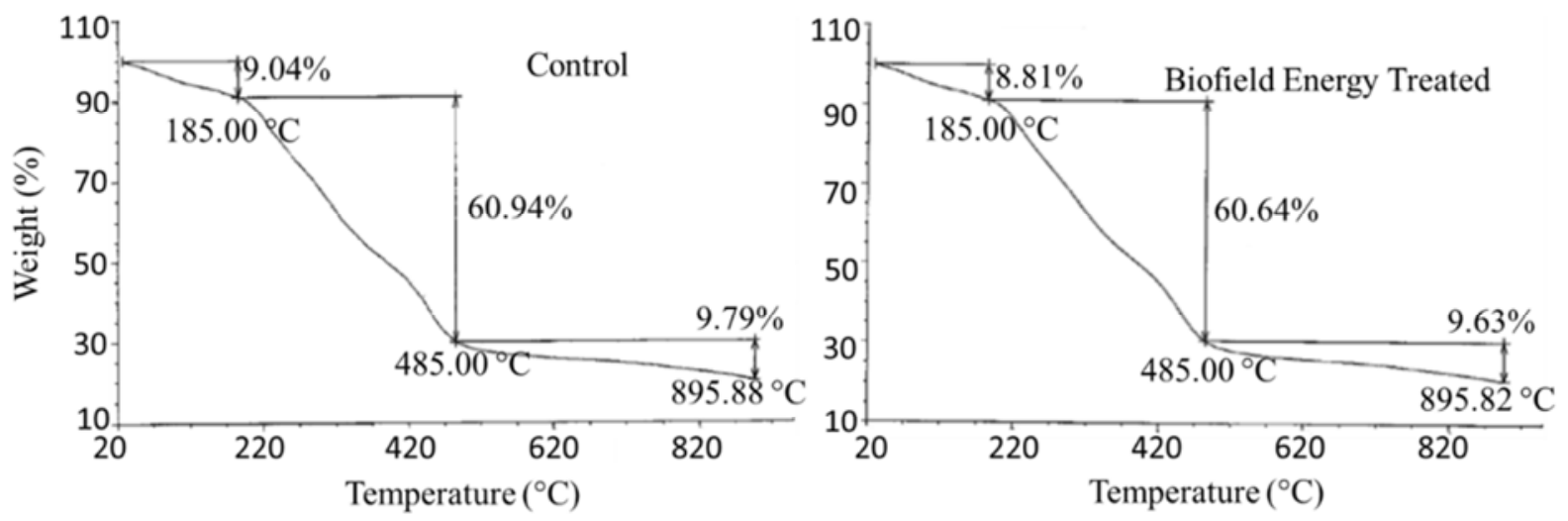

Figure 5. TGA thermograms of the control and Biofield Energy Treated W. somnifera (Ashwagandha) root extract.

The DTG thermograms of the control and Biofield Energy Treated samples (Figure 6) displayed two broad peaks. The maximum thermal degradation temperature at $273.53^{\circ} \mathrm{C}$ and $389.39^{\circ} \mathrm{C}$ for two broad peaks in the Biofield Energy Treated ashwagandha root extract was increased by $0.78 \%$ and

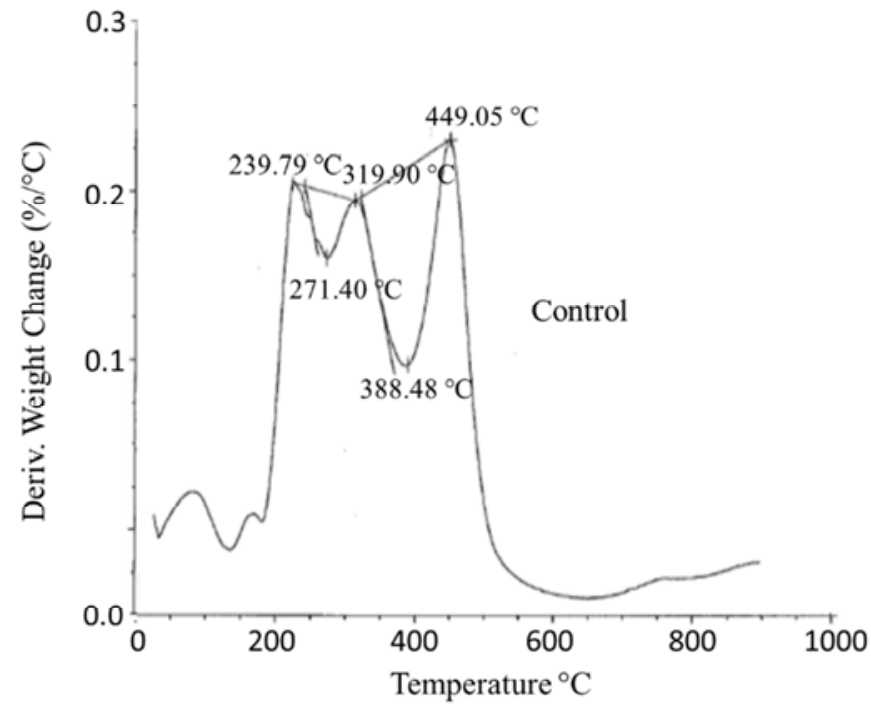

$0.31 \%$, respectively compared to the control the sample $\left(271.40^{\circ} \mathrm{C}\right.$ and $\left.388.48^{\circ} \mathrm{C}\right)$. Overall, an improvement in the thermal stability of the Biofield Energy Treated ashwagandha was increased compared to the control sample.

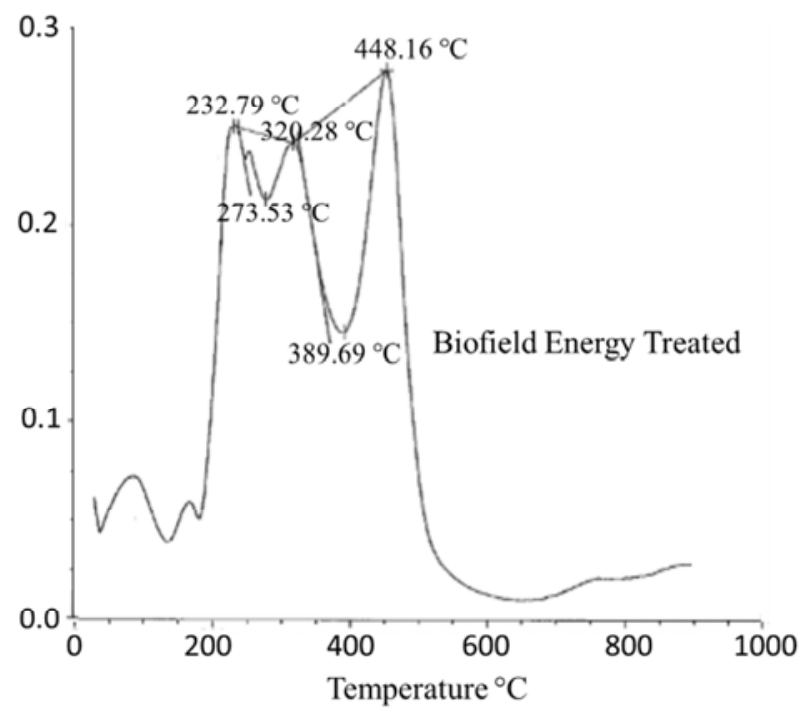

Figure 6. The DTG thermograms of the control and Biofield Energy Treated W. somnifera root extract.

\subsection{Differential Scanning Calorimetry (DSC) Analysis}

The DSC thermograms of both the control and Biofield Energy Treated ashwagandha root extract are presented in the Figure 7 and Table 4. The DSC thermograms of the control and Biofield Energy Treated samples indicated the presence of a broad endothermic inflection at $80.83^{\circ} \mathrm{C}$ and $89.68^{\circ} \mathrm{C}$, respectively which is not the true melting point of the
Biofield Energy Treated ashwagandha root extract powder. It may be the evaporation of the bounded water present in the sample. This evaporation temperature was significantly increased by $10.95 \%$ in the Biofield Energy Treated sample with a $5.34 \%$ reduced latent heat of vaporization compared with the control sample (Table 4).

Table 4. The melting point $\left({ }^{\circ} \mathrm{C}\right)$ and latent heat of fusion $(J / G)$ values of the control and Biofield Energy Treated W. somnifera (Ashwagandha) root extract.

\begin{tabular}{lllll}
\hline Sample & $\begin{array}{l}\text { Onset vaporization } \\
\text { temperature }\left(\mathbf{T}_{\text {onset }}\right)^{\circ} \mathbf{C}\end{array}$ & $\begin{array}{l}\text { Peak vaporization } \\
\text { temperature }\left(\mathbf{T}_{\text {peak }}\right)^{\circ} \mathbf{C}\end{array}$ & $\begin{array}{l}\text { Endset vaporization } \\
\text { temperature }\left(\mathbf{T}_{\text {endset }}\right)^{\circ} \mathbf{C}\end{array}$ & $\begin{array}{l}\text { Latent heat of vaporization } \\
\left(\Delta \mathbf{H}_{\text {vaporization }}\right) \mathbf{J} / \mathbf{g}\end{array}$ \\
\hline Control & 39.19 & 80.83 & 110.23 & 149.83 \\
Biofield Energy Treated & 52.25 & 89.68 & 119.57 & 141.83 \\
\% Change* & 33.32 & 10.95 & 8.47 & -5.34 \\
\hline
\end{tabular}

$\mathrm{T}_{\text {onset: }}$ Onset vaporization temperature, $\mathrm{T}_{\text {peak }}$ : Peak vaporization temperature, $\mathrm{T}_{\text {endset: }}$ Endset vaporization temperature, $\Delta \mathrm{H}$ : Latent heat of vaporization, ${ }^{\mathrm{a}} \mathrm{denotes}$ the percentage change of the Biofield Energy Treated sample with respect to the control sample. 

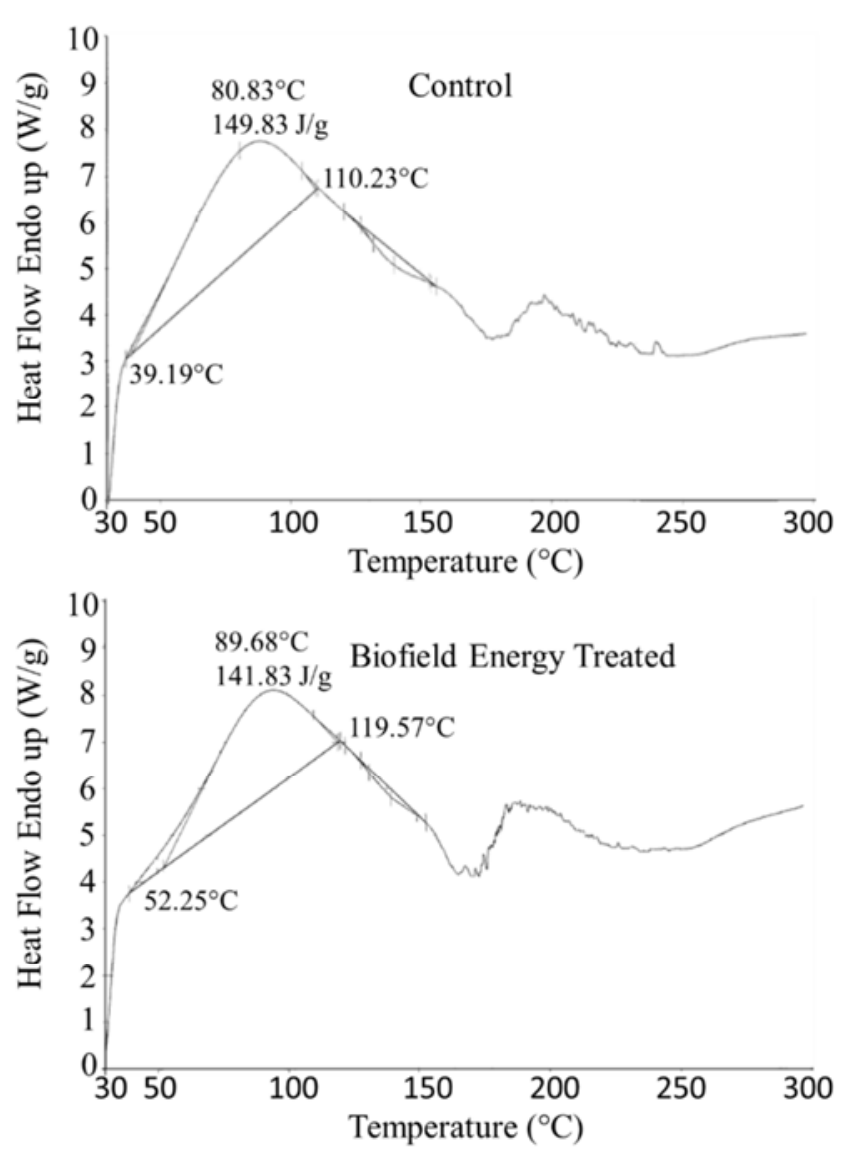

Figure 7. DSC thermograms of the control and Biofield Energy Treated W. somnifera (Ashwagandha) root extract.

It is assumed that the Biofield Energy Healing Treatment might altered the intermolecular force in the Biofield Energy Treated sample, which probably increase the heat change. These results suggest that the temperature for water removal of the Biofield Energy Treated sample was significantly increased as compared to the control sample. However, the Biofield Energy Treated, and control $W$. somnifera indicated several endothermic peak around $200^{\circ} \mathrm{C}$ (Figure 7). Several small endothermic peaks were also observed in the thermogram of both in control and treated samples, which may be due to the multiple phytoconstituents present in the root extract in a very small concentration $[60,61]$. In the Biofield Energy Treated sample the endothermic peak was sharp and significantly prominent as compared to the control sample.

\section{Conclusions}

The present research work revealed that The Trivedi Effect ${ }^{\circledR}$ - Consciousness Energy Healing Treatment (Biofield Energy Healing Treatment) has the outstanding capability for increase the thermal stability and particle size of the ashwagandha root extract along with decreased surface area. The PXRD analysis exhibited that both the control and treated samples were amorphous in nature. The particle size values of the Biofield Energy Treated sample at $\mathrm{d}_{10}, \mathrm{~d}_{50}$, and $\mathrm{d}_{90}$ were significantly increased by $8.69 \%, 7.32 \%$, and $6.50 \%$, respectively compared with the control sample. Similarly, the surface area of the treated sample was significantly decreased by $12.69 \%$ compared to the control sample. The TGA revealed the two major thermal degradation steps and the total weight loss was decreased by $0.86 \%$ in the treated sample compared with the control sample. Consequently, the maximum thermal degradation temperature at $273.53^{\circ} \mathrm{C}$ and $389.39^{\circ} \mathrm{C}$ for two broad peaks in treated sample was increased by $0.78 \%$ and $0.31 \%$, respectively compared to the control the sample $\left(271.40^{\circ} \mathrm{C}\right.$ and $\left.388.48^{\circ} \mathrm{C}\right)$. The DSC analysis indicated that the evaporation temperature was significantly increased by $10.95 \%$ in the Biofield Energy Treated sample with a 5.34\% reduced latent heat of vaporization compared with the control sample. The overall thermal analysis indicated that the treated sample was thermally more stable as compared to the control sample. In summary, The Trivedi Effect $^{\circledR}$ - Energy of Consciousness Healing Treated ashwagandha root extract could have better powder flowability and long-term storage stability compared with the control sample and could be suitable for any oral pharmaceutical and nutraceutical formulation which might be providing better therapeutic response against various diseases such as diabetes mellitus, allergies and septic shock; stress-related disorders like sleep disorder, insomnia, anxiety, depression, Attention Deficit Disorder (ADD), Attention Deficit Hyperactive Disorder (ADHD), mental restlessness (mind chattering), brain frog, low libido, impotency, lack of motivation, mood swings, fear of the future, confusion, migraines, headaches, forgetfulness, overwhelm, loneliness, worthlessness, indecisiveness, frustration, irritability, chronic fatigue, obsessive/compulsive behavior and panic attacks; inflammatory diseases and immunological disorders like Lupus, Systemic Lupus Erythematosus, Hashimoto Thyroiditis, Type 1 Diabetes, Asthma, Chronic peptic ulcers, Tuberculosis, Hepatitis, Chronic active hepatitis, Celiac Disease (gluten-sensitive enteropathy), Addison Disease, Crohn's disease, Graves' Disease, Pernicious and Aplastic Anemia, Sjogren Syndrome, Irritable Bowel Syndrome (IBS), Multiple Sclerosis, Rheumatoid arthritis, Chronic periodontitis, Ulcerative colitis, Chronic sinusitis, Myasthenia Gravis, Atherosclerosis, Vasculitis, Dermatitis, Diverticulitis, Rheumatoid Arthritis, Reactive Arthritis, Alopecia Areata, Psoriasis, Scleroderma, Fibromyalgia, Chronic Fatigue Syndrome and Vitiligo, agingrelated diseases like cardiovascular disease, arthritis, cancer, Alzheimer's disease, dementia, cataracts, osteoporosis, diabetes, hypertension, glaucoma, hearing loss, Parkinson's Disease, Huntington's Disease, Prion Disease, Motor Neurone Disease, Spinocerebellar Ataxia, Spinal muscular atrophy, Amyotrophic lateral sclerosis, Friedreich's Ataxia and Lewy Body Disease, chronic infections, and many more.

\section{Abbreviations}

DSC: Differential scanning calorimetry, FT-IR: Fourier transform infrared spectroscopy, HOMO: Highest energy 
occupied molecular orbital, LUMO: Lowest energy unoccupied molecular orbital, TGA: Thermal gravimetric analysis, $\mathrm{T}_{\text {peak }}=$ Peak vaporization temperature, $\Delta \mathrm{H}$ : Latent heat of vaporization, UV-vis: Ultraviolet-visible spectroscopy, PSD: Particle size distribution; PXRD: Powder $\mathrm{X}$-ray diffraction.

\section{Acknowledgements}

The authors gratefully acknowledged to GVK Biosciences Pvt. Ltd., Trivedi Science, Trivedi Global, Inc. and Trivedi Master Wellness for the assistance and support during the work.

\section{References}

[1] Kesarwani K, Gupta R (2013) Bioavailability enhancers of herbal origin: An overview. Asian Pac J Trop Biomed 3: 253266.

[2] Singh N, Bhalla M, Jager P, Gilca M (2011) An overview on ashwagandha: A rasayana (rejuvenator) of Ayurveda. Afr J Tradit Complement Altern Med 8: 208-213.

[3] Alam N, Hossain M, Mottalib MA, Sulaiman SA, Gan SH, Khalil MI (2012) Methanolic extracts of Withania somnifera leaves, fruits and roots possess antioxidant properties and antibacterial activities. BMC Complement Altern Med 12: 175 .

[4] Parihar P, Shetty R, Ghafourifar P, Parihar MS (2016) Increase in oxidative stress and mitochondrial impairment in hypothalamus of streptozotocin treated diabetic rat: Antioxidative effect of Withania somnifera. Cell Mol Biol (Noisy-le-grand) 62: 73-83.

[5] Choudhary B, Shetty A, Langade DG (2015) Efficacy of Ashwagandha (Withania somnifera [L.] Dunal) in improving cardiorespiratory endurance in healthy athletic adults. Ayu 36: 63-68.

[6] Halder B, Singh S, Thakur SS (2015) Withania somnifera root extract has potent cytotoxic effect against human malignant melanoma cells. PLoS One 10: e0137498.

[7] Verma SK, Kumar A (2011) Therapeutic uses of Withania somnifera (ashwagandha) with a note on withanolides and its pharmacological actions. Asian J Pharm Clin Res 4: 1-4.

[8] Shah N, Singh R, Sarangi U, Saxena N, Chaudhary A, Kaur G, Kaul SC, Wadhwa R (2015) Combinations of ashwagandha leaf extracts protect brain-derived cells against oxidative stress and induce differentiation. PLoS One 10: e0120554.

[9] Al-Awthan YS, Hezabr SM, Al-Zubairi AM, Al-Hemiri FA (2014) Effects of aqueous extract of Withania somnifera on some liver biochemical and histopathological parameters in male guinea pigs. Pak J Biol Sci 17: 504-510.

[10] Nema R, Jain P, Khare S, Pradhan A, Gupta A, Singh D (2012) Study of Withania somnifera with the spatial reference of phytochemical, FTIR and flavonoids quantification. Int J Pharm Life Sci 3: 1530-1532.

[11] Kumar V, Dey A, Hadimani MB, Marcović T, Emerald M (2015) Chemistry and pharmacology of Withania somnifera:
An update. Tang (Humanitas Medicine) 5: e1.

[12] Misra L, Mishra P, Pandey A, Sangwan RS, Sangwan NS, Tuli $\mathrm{R}$ (2008) Withanolides from Withania somnifera roots. Phytochemistry 69: 1000-1004.

[13] Lala P, Misra L, Sangwana RS, Tuli R (2006) New withanolides from fresh berries of Withania somnifera $\mathrm{Z}$. Naturforsch 61b: 1143-1147.

[14] Zhao J, Nakamura N, Hattori M, Kuboyama T, Tohda C, Komatsu K (2002) Withanolide derivatives from the roots of Withania somnifera and their neurite outgrowth activities. Chem Pharm Bull 50: 760-765.

[15] Budhiraja RD, Krishan P, Sudhir S (2000) Biological activity of withanolides. J Sci Ind Res 59: 904-911.

[16] Baitharu I, Jain V, Deep SN, Shroff S, Sahu JK, Naik PK, Ilavazhagan G (2014) Withanolide A prevents neurodegeneration by modulating hippocampal glutathione biosynthesis during hypoxia. PLoS One 9: e105311.

[17] Sangwan NS, Sabir F, Mishra S, Bansal S, Sangwan RS (2014) Withanolides from Withania somnifera Dunal: Development of cellular technology and their production. Recent Pat Biotechnol 8: 25-35.

[18] $\mathrm{Ku} \mathrm{SK,} \mathrm{Bae} \mathrm{JS} \mathrm{(2014)} \mathrm{Antiplatelet,} \mathrm{anticoagulant,} \mathrm{and}$ profibrinolytic activities of withaferin A. Vascul Pharmacol 60: $120-126$.

[19] Gao S, Li H, Zhou XQ, You JB, Tu DN, Xia G, Jiang JX, Xin C (2015) Withaferin A attenuates lipopolysaccharide-induced acute lung injury in neonatal rats. Cell Mol Biol (Noisy-legrand) 61: 102-106.

[20] Stenger VJ (1999) Bioenergetic fields. Sci Rev Alternative Med 3.

[21] Rogers, M (1989) "Nursing: A Science of Unitary Human Beings." In J. P. Riehl-Sisca (ed.) Conceptual Models for Nursing Practice. $3^{\text {rd }}$ Edn. Norwark: Appleton \& Lange.

[22] Rubik B (2002) The biofield hypothesis: Its biophysical basis and role in medicine. J Altern Complement Med 8: 703-717.

[23] Nelson LA, Schwartz GE (2005) Human biofield and intention detection: Individual differences. J Altern Complement Med 11: 93-101.

[24] Nemeth L (2008) Energy and biofield therapies in practice. Beginnings 28: 4-5.

[25] Koithan M (2009) Introducing complementary and alternative therapies. J Nurse Pract 5: 18-20.

[26] Trivedi MK, Patil S, Shettigar H, Mondal SC, Jana S (2015) The potential impact of biofield treatment on human brain tumor cells: A time-lapse video microscopy. J Integr Oncol 4: 141 .

[27] Trivedi MK, Patil S, Shettigar H, Gangwar M, Jana S (2015) An effect of biofield treatment on multidrug-resistant Burkholderia cepacia: A multihost pathogen. J Trop Dis 3: 167.

[28] Trivedi MK, Patil S, Shettigar H, Bairwa K, Jana S (2015) Phenotypic and biotypic characterization of Klebsiella oxytoca: An impact of biofield treatment. J Microb Biochem Technol 7: 203-206. 
[29] Trivedi MK, Branton A, Trivedi D, Shettigar H, Nayak G, Mondal SC, Jana S (2015) Antibiogram, biochemical reactions and genotyping characterization of biofield treated Staphylococcus aureus. American Journal of BioScience 3: 212-220.

[30] Trivedi MK, Patil S, Shettigar H, Bairwa K, Jana S (2015) Effect of biofield treatment on phenotypic and genotypic characteristic of Provindencia rettgeri. Mol Biol 4: 129.

[31] Trivedi MK, Branton A, Trivedi D, Nayak G, Gangwar M, Jana S (2015) Bacterial identification using 16S rDNA gene sequencing and antibiogram analysis on biofield treated pseudomonas fluorescens. Clin Med Biochemistry Open Access 1: 101.

[32] Trivedi MK, Branton A, Trivedi D, Nayak G, Gangwar M, Jana S (2015) Antibiogram, biochemical reactions, and genotypic pattern of biofield treated Pseudomonas aeruginosa. J Trop Dis 4: 181.

[33] Trivedi MK, Branton A, Trivedi D, Nayak G, Mondal SC, Jana S (2015) Biochemical differentiation and molecular characterization of biofield treated Vibrio parahaemolyticus. American Journal of Clinical and Experimental Medicine 3: 260-267.

[34] Trivedi MK, Tallapragada RM (2008) A transcendental to changing metal powder characteristics. Metal Powder Report 31: $22-38$.

[35] Dabhade VV, Tallapragada RMR, Trivedi MK (2009) Effect of external energy on the atomic, crystalline, and powder characteristics of antimony and bismuth powders. Bull Mater Sci 32: 471-479.

[36] Trivedi MK, Patil S, Tallapragada RM (2013) Effect of bio field treatment on the physical and thermal characteristics of vanadium pentoxide powders. J Material Sci Eng S 11: 001.

[37] Trivedi MK, Branton A, Trivedi D, Nayak G, Saikia G, Jana S (2015) Physical and structural characterization of biofield treated imidazole derivatives. Nat Prod Chem Res 3: 187.

[38] Trivedi MK, Tallapragada RM, Branton A, Trivedi D, Nayak G, Mishra RK, Jana S (2015) Characterization of physical, spectral and thermal properties of biofield treated 1,2,4Triazole. J Mol Pharm Org Process Res 3: 128.

[39] Trivedi MK, Mohan R, Branton A, Trivedi D, Nayak G, Latiyal O, Jana S (2015) Evaluation of biofield energy treatment on physical and thermal characteristics of selenium powder. Journal of Food and Nutrition Sciences 3: 223-228.

[40] Trivedi MK, Nayak G, Patil S, Tallapragada RM, Jana S, Mishra RK (2015) Bio-field treatment: An effective strategy to improve the quality of beef extract and meat infusion powder. J Nutr Food Sci 5: 389.

[41] Trivedi MK, Branton A, Trivedi D, Nayak G, Singh R, Jana S (2015) Evaluation of physical, thermal and spectroscopic properties of biofield treated $p$-hydroxyacetophenone. Nat Prod Chem Res 3: 190.

[42] Trivedi MK, Branton A, Trivedi D, Nayak G, Panda P, Jana S (2016) Gas chromatography-mass spectrometric analysis of isotopic abundance of ${ }^{13} \mathrm{C},{ }^{2} \mathrm{H}$, and ${ }^{18} \mathrm{O}$ in biofield energy treated $p$-tertiary butylphenol (PTBP). American Journal of Chemical Engineering 4: 78-86.

[43] Trivedi MK, Branton A, Trivedi D, Nayak G, Mishra RK,
Jana S (2015) Characterization of physical, thermal and spectral properties of biofield treated 2-aminopyridine. Science Journal of Analytical Chemistry 3: 127-134.

[44] Trivedi MK, Branton A, Trivedi D, Nayak G, Gangwar M, Jana S (2015) Agronomic characteristics, growth analysis, and yield response of biofield treated mustard, cowpea, horse gram, and groundnuts. International Journal of Genetics and Genomics 3: 74-80.

[45] Trivedi MK, Branton A, Trivedi D, Nayak G, Mondal SC, Jana S (2015) Evaluation of plant growth, yield and yield attributes of biofield energy treated mustard (Brassica juncea) and chick pea (Cicer arietinum) seeds. Agriculture, Forestry and Fisheries 4: 291-295.

[46] Devkar ST, Kandhare AD, Sloley BD, Jagtap SD, Lin J, Tam YK, Katyare SS, Bodhankar SL, Hegde MV (2015) Evaluation of the bioavailability of major withanolides of Withania somnifera using an in vitro absorption model system. J Adv Pharm Technol Res 6: 159-164.

[47] Verma SK, Kumar A (2011) Therapeutic uses of Withania somnifera (ashwagandha) with a note on withanolides and its pharmacological actions. Asian J Pharm Clin Res 4: 1-4.

[48] Chereson R (2009) Bioavailability, bioequivalence, and drug selection. In: Makoid CM, Vuchetich PJ, Banakar UV (eds) Basic pharmacokinetics $\left(1^{\text {st }}\right.$ edn) Pharmaceutical Press, London.

[49] Blagden N, de Matas M, Gavan PT, York P (2007) Crystal engineering of active pharmaceutical ingredients to improve solubility and dissolution rates. Adv Drug Deliv Rev 59: 617630 .

[50] Trivedi MK, Mohan TRR (2016) Biofield energy signals, energy transmission and neutrinos. American Journal of Modern Physics 5: 172-176.

[51] Khadka P, Ro J, Kim H, Kim I, Kim JT, Kim H, Cho JM, Yun G, Lee J (2014) Pharmaceutical particle technologies: An approach to improve drug solubility, dissolution and bioavailability. Asian J Pharm Sci 9: 304-316.

[52] Kale VV, Gadekar S, Ittadwar AM (2011) Particle size enlargement: Making and understanding of the behavior of powder (particle) system. Syst Rev Pharm 2: 79.

[53] Reichenbacher M, Popp J (2012) Challenges in Molecular structure determination, DOI 10.1007/978-3-642-24390-5 2, Springer-Verlag Berlin Heidelberg.

[54] Stuart BH (2004) Infrared spectroscopy: Fundamentals and applications in Analytical Techniques in the Sciences. John Wiley \& Sons Ltd., Chichester, UK.

[55] Joshi P, Misra L, Siddique AA, Srivastava M, Kumar S, Darokar MP (2014) Epoxide group relationship with cytotoxicity in withanolide derivatives from Withania somnifera. Steroids 79: 19-27.

[56] Misra L, Lal P, Chaurasia ND, Sangwan RS, Sinha S, Tuli R (2008) Selective reactivity of 2 -mercaptoethanol with $5 \beta, 6 \beta$ epoxide in steroids from Withania somnifera. Steroids 73: 245-251.

[57] Gu M, Yu Y, Gunaherath GMKB, Leslie Gunatilaka AA, Li D, Sun D (2014) Structure-activity relationship (SAR) of withanolides to inhibit $H s p 90$ for its activity in pancreatic cancer cells. Invest New Drugs 32: 68-74. 
[58] Ramachandran A, Kumar MS (2014) FT-IR, UV and antimicrobial activity Withania somnifera and Withania obtusifolia. Int J Pharm Bio Sci 5: (B) 111-117.

[59] Hesse M, Meier H, Zeeh B (1997) Spectroscopic methods in organic chemistry, Georg Thieme Verlag Stuttgart, New York.

[60] Srivastava A, Alam S, Shahbaaz S, Tiwari M, Mittal A,
Chauhan S (2014) Formulation and evaluation of antiacne cream containing Withania somnifera. J Pharm Sci Inv 3: 348352.

[61] Mitra D, Francis S, Varshney L (2004) Calorimetry thermal investigations on $\gamma$ radiation processed natural medicinal products (ashwagandha, amla and hartiki) J Therm Anal Cal 78: 821-829. 